\title{
MET DEN GOUVERNEUR-GENERAAL OP REIS IN 1822.
}

\author{
DOOR \\ R. A. KERN. \\ (Met platen). ${ }^{1}$ )
}

I.

In 1829 verscheen anonym zonder vermelding van den naam des uitgevers, gedrukt op papier dat het watermerk ,van Gelder” draagt, een Fransch boek: „Lettres de Java, ou Journal d'un voyage dans „,cette île, en 1822." - 't Is een verzameling brieven, aan een vriend in patria, 't zij Noord- 't zij Zuid-Nederlander, geschreven. Zij bevatten indrukken van de reis door den Gouverneur-Generaal van der Capellen in dat jaar over het grootste gedeelte van Java ondernomen. De Bataviasche Courant - in 1828 in Javasche Courant herdoopt vermeldt in het nummer van 29 Juli 1822 Bijvoegsel dat de Gouverneur-Generaal met gevolg, eenige dagen tevoren, van Batavia was vertrokken om een reis over Java te ondernemen. De namen der deelnemers worden meegedeeld: de Gouverneur-Generaal en mevrouw van der Capellen, een militair arts, twee adjudanten, een Raad van Indië als fungeerend Hoofd-Inspecteur van Financiën en de Secretaris der Hooge Regeering Mr. J. Schneither. De „Lettres de Java" noemt hen allen maar bovendien nog twee anderen die blijkbaar niet hoog genoeg gestegen waren op den ambtelijken ladder om voor vermelding in het officieele nieuwsblad in aanmerking te komen, t.w. C. van Angelbeek, translateur van het Gouvernement en hemzelf.

Wie was hij ? Toen men op 22 Juli van Buitenzorg in rijtuigen de reis naar Tjiandjoer aanvaardde, was hij met Schneither in één rijtuig gezeten en tijdens de reis werkte hij met dezen samen, hij was van regeeringszaken op de hoogte. Hij zal dus een jong Secretarieambtenaar geweest zijn, iemand die in aanmerking kwam om mettertijd tot een hoog ambt te stijgen.

1) Zie voor beschrijving der platen, achteraan. 
De Almanak van Nederlandsch-Indië voor 1822 , de latere Regeeringsalmanak, noemt onder „Hooge Regeering” den GouverneurGeneraal, de Raden van Indië, den Algemeenen Secretaris, den Secretaris der Hooge Regeering Schneither bovengenoemd, en C. P. J. Elout, Secretaris van het Departement der Inlandsche zaken. Hierop volgt, met onderhoofd: Algemeene Secretarie, een reeks kommiezen, klerken, boden, en met onderhoofd: Departement van Inlandsche zaken, Elout voornoemd, thans Secretaris van het Gouvernement voor de Inlandsche zaken geheeten, de tolk van Angelbeek, drie élèves voor de Inlandsche zaken te Batavia, één élève te Soerakarta plus een paar klerken. Onder dit gezelschap houdt zich dé onbekende schrijver verscholen. In zijn brieven wijdt hij aandacht aan alles wat de Inlandsche maatschappij betreft en zij verraden ook kennis van Inlandsche volksverhalen. Dit laatste is voor dien tijd iets zóó bijzonders dat de keuze al dadelijk beperkt wordt tot de weinigen bij wie zulke kennis aanwezig kon worden geacht. Dat waren de élèves voor de Inlandsche talen.

Bij resolutie van 3 Februari 1819 no. 3, waarschijnlijk het besluit waarbij het ambt werd geschapen, was bepaald dat zoo de élèves zich door ijver en bekwaamheid onderscheidden, zij eenmaal op de eerste posten konden rekenen ${ }^{1}$ ). Doch eerst in 1820 werd op voordracht van Elout het Departement der Inlandsche zaken opgericht, waar de élèves onder werden gebracht ${ }^{2}$ ), hij zelf kwam aan het hoofd te staan. O.a. liet hij Inlandsche kronieken en oude geschriften nagaan en vertalen ${ }^{3}$ ). Zoo verwierven daarvan de élèves de kennis die ook de briefschrijver blijkt te bezitten.

Elout heeft de reis over Java zelf niet meegemaakt. Hij zou als leider van het Departement voor Inlandsche zaken in de eerste plaats in aanmerking gekomen zijn, maar hij bevond zich niet op Java, hij was in Januari 1822 met verlof naar Nederland vertrokken. Er waren aanvang 1822 drie élèves te Batavia: P. P. Roorda van Eysinga, J. H. Hofmeijer en J. E. de Stürler. Van den eersten zegt het biografisch woordenboek van v. d. Aa, in navolging van wat hij zelf schrijft, dat hij 16 Juli 1822 als ambtenaar voor Palembang werd aangewezen. Daar de reis van den Gouverneur-Generaal over Java

1) P. P. Roorda van Eysinga, Verschillende reizen en lotgevallen II, 315. Amsterdam 1832.

2) W. R. van Hoëvell, Geschiedkundig Overzigt van de beoefening van kunsten en wetenschappen in Nederlands Indië 90. - Batavia 1839.

3) Roorda van Eysinga, III, 150. 
duurde van Juli tot November, zou het dus uitgesloten zijn geweest dat hij de reis meemaakte, als de opgave van Roorda van Eysinga juist ware. Maar zij is niet juist. Hij schrijft (o.c. III 152) dat hij op genoemden datum als ambtenaar voor Palembang werd aangewezen met de heeren Kruseman, Reijnst en Olivier. Doch door Olivier weten wij dat het gezelschap in 1823 naar Palembang vertrok ${ }^{1}$ ), wat wordt bevestigd door de Bataviasche Courant van 5 Juli 1823 no. 27 welke de benoeming meldt van Reijnst tot adjunct-kommissaris van Palembang om bij beëindiging der zending van den Regeeringskommissaris als Resident op te treden. Als zoodanig verschijnt hij dan ook in den Almanak vooor 1824.

't Is grappig te vernemen hoe Olivier en Roorda over de reis aan boord van het schip dat hen van Batavia naar Palembang overbracht dachten. Olivier merkt op dat voor den overtocht aan den kapitein van het schip een ,wissewasje" van 66 ropijen per dag betaald werd ,voor pudding en beefstakes" (o.c. II 327), Roorda van Eysinga is in de wolken, spijzen en dranken waren uitmuntend, de bediening onverbeterlijk zoodat hij de overtochtskosten met genoegen aan den gezagvoerder overhandigde (o.c. III 159).

Roorda van Eysinga zou dus, wat den tijd betreft, aan de reis van den Gouverneur-Generaal hebben kunnen deelnemen. Maar er zijn andere bezwaren. Zijn bovenaangehaalde werk: „Verschillende reizen en lotgevallen", is een langdradige, tot in de onbelangrijkste bizonderheden afdalende levensbeschijving. Hij doet zich hierin kennen als een praatvâer, die met groote zelfingenomenheid uiterst oppervlakkig, zonder kritisch oordeel in en uit praat. In het jaar 1820 heeft hij Blüme op een rondreis over Java in het belang der vaccine vergezeld. Deze reis bood hem de gelegenheid, naar hij zegt, door omgang met den Inlander zijne gewoonten, godsdienstige begrippen, leven en denkwijze te leeren (o.c. II 318). In hoeverre hij daarin geslaagd is, kan een ieder nagaan die het reisverslag leest. Blüme volgde nagenoeg dezelfde route als de Gouverneur-Generaal twee jaar na hem. Legt men nu Roorda van Eysinga's reisverslag naast dat van den briefschrijver dan blijken zij in alle opzichten zoo verschillend te zijn dat ze onmogelijk uit één pen gevloeid kunnen zijn. De briefschrijver is getroffen door de schoonheid van Java's natuur en weet dit tot uitdrukking te brengen, manieren en gewoonten der Inlandsche grooten

1) J. Olivier, Land- en zeetogten in Nederland's Indië, II, 327. - Amsterdam 1828. 
hebben zijn aandacht, aan Roorda van Eysinga gaat dit alles voorbij, wat valsch pathos daargelaten. Beiden bezoeken de Baraboedoer, wat zij erover zeggen, heeft niets gemeen. De onbekende vindt te Basoeki "rien de remarquable" (o.c. 151), de ander, aldaar aankomende, vindt dit landschap „het ware elysium van Java” (o.c. III 138). Men kan bijna van bladzijde tot bladzijde de tegenstellingen aanwijzen.

Van Roorda van Eysinga kan dus geen sprake zijn. Trouwens, van iemand die alle zijne wederwaardigheden uitpluist en alle eer en lof die zijn deel zijn geweest, niet nalaat te vermelden, mag verwacht worden dat hij zijn deelname aan de reis van den Gouverneur-Generaal niet onder stoelen en banken gestoken zou hebben.

Van J. E. de Stürler, den tweeden élève, is uit het familie-boek bekend dat hij in 1800 geboren werd te Tiel, in 1817 als 2de luitenant in militairen dienst trad, in 1820 in burgerlijken dienst overging. Helaas leeren wij hieruit niets omtrent zijn opvoeding en daar komt het juist op aan daar uit de brieven een beschaafd, ontwikkeld man spreekt, die ook Latijn kende. Het familieboek meldt verder dat hij twee boeken geschreven heeft, in 1836 gaf hij een beknopte vertaling van Raffles' History of Java in het licht en in 1840 Reizen uit OostIndië naar Europa, in Engeland, Nederland, Duitschland en Zwitserland. Dit laatste werk levert geen aanknoopingspunten met de Lettres de Java. Ten slotte noemt het familieboek de brieven niet. Dit is wel geen bewijs tegen zijn auteurschap, maar er is toch een redelijke kans dat het geschrift wel vermeld zou zijn, als de Stürler werkelijk de schrijver ware. Alles tesamen genomen lijkt hij mij niet in aanmerking te komen.

Blijft als laatste élève J. H. Hofmeijr. Zijn eenige aanbevelingsbrief is dat de beide andere élèves niet de schrijver zijn. Er zijn mij omtrent hem slechts enkele officieele gegevens bekend. Medio 1823 werd hij tot assistent-resident voor de politie te Batavia benoemd, hij was toen kommies op het Assistent-Residentie kantoor aldaar. Later komt hij elders als bestuursambtenaar voor. $\mathrm{Er}$ is dus geen enkele positieve aanwijzing dat hij de schrijver der brieven zou zijn geweest. Zijn kansen zouden stijgen als zou blijken dat hij uit België stamde. Immers hij schrijft Fransch met groote vaardigheid en de eenige Europeesche plaats die hij in zijn brieven noemt, is Brussel.

Onder de kommiezen ter Algemeene Secretarie neemt in 1822 de eerste plaats in J. F. F. (1. T) Mayor, als hoofdkommies, later werd hij resident van Soerakarta (1834). Van 's mans opvoeding is mij niets bekend, eenige kennis van de Inlandsche wereld, zooals uit de 


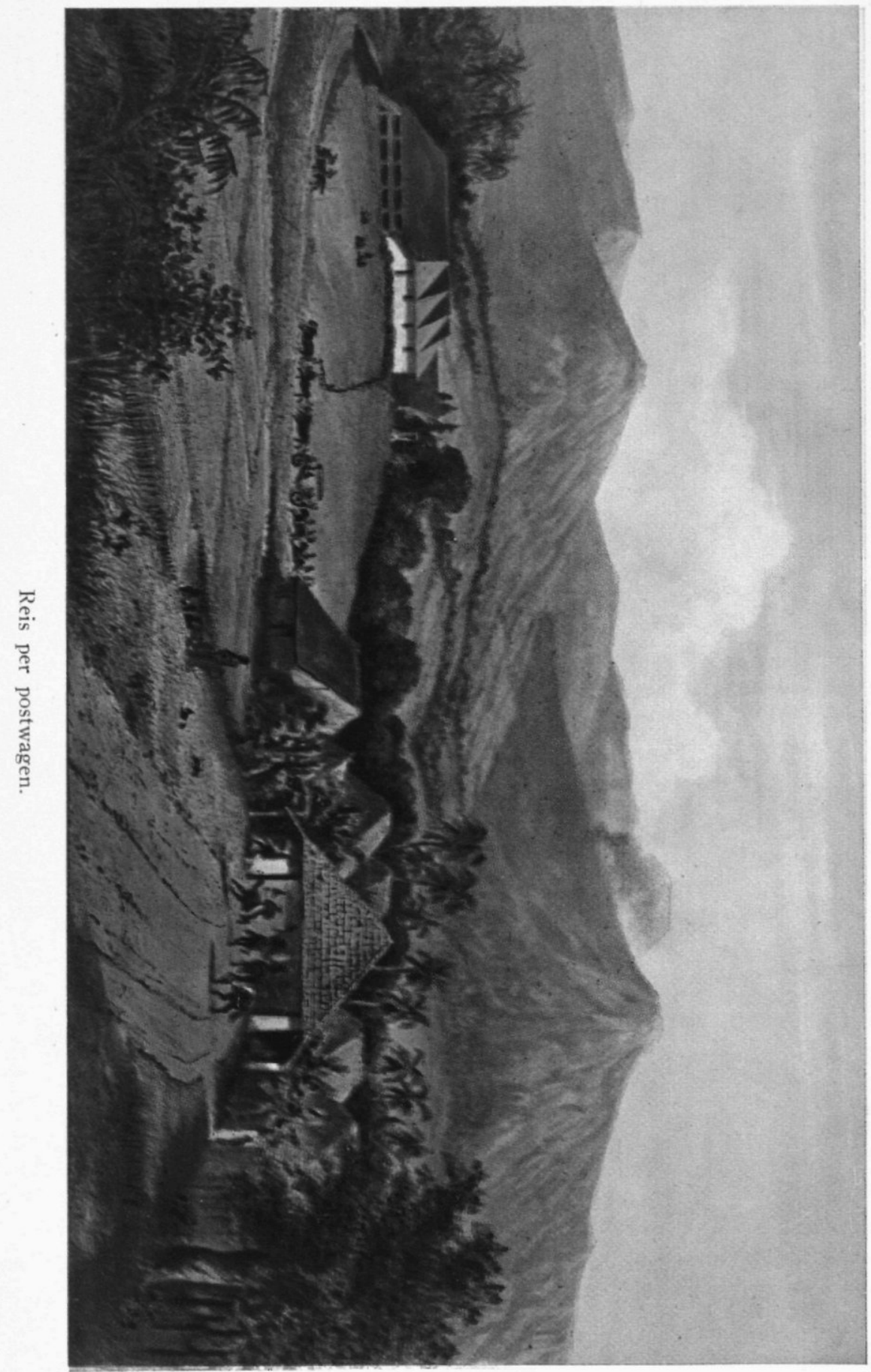


brieven spreekt, was hem in zijn kommiezentijd niet toe te kennen, hij komt niet als de schrijver in aanmerking.

De naam van den schrijver blijft dus onzeker maar dat doet aan de belangrijkheid van hetgeen hij te zeggen heeft, niet af. Men zou zijn naam willen weten om zijn nagedachtenis de eer te kunnen brengen die zijn geschrift toekomt, nu kunnen wij slechts de onbekendheid welke hij gezocht heeft, eerbiedigen. Hij schrijft, als gezegd, gemakkelijk Fransch, hij is een intelligent en nauwkeurig waarnemer, in het bizonder de kleedij der Inlandsche grooten trof zijn aandacht, hij weet die goed en duidelijk te beschrijven, zóó dat zijn mededeelingen voor wie studie van het costuum willen maken, haar waarde hebben behouden. Wij zullen daarover evenmin als over zijn beschrijvingen van de natuur waarvoor zijn gemoed open stond, spreken, belangstellenden naar de brieven verwijzende.

Voor Inlandsche kunst en muziek had hij oog noch oor, hij is niet bij machte daarin iets anders dan curiositeiten te zien; het Javaansche leven was ook voor hem te zeer een gesloten boek om tot een waardeering te geraken. Intusschen deelt hij er wel een en ander over mede dat ons uit historiscch oogpunt belang kan inboezemen.

\section{II.}

De tocht duurde drie maanden. Men vertrok steeds vóór dag en dauw, zoodat van de schoonheid van den aanlichtenden dag over het Javaansche landschap steeds ten volle genoten kon worden. Er werd vrij vlug gereisd omdat van wagen en paard gebruik gemaakt kon worden, de reis strekte zich uit van Batavia tot Banjoewangi, alleen Bantěn liet men terzijde. Van Samarang uit werd een rondgang door de Vorstenlanden gemaakt, d.w.z. door de nagaragoeng, over Soerakarta en Jogjakarta, de mantjanagara: Banjoemas, Bagĕlen, Madioen en Kaḍiri - men was in 1822 ! — bleven onbezocht.

Hajam Woeroek beperkte bijna vijf eeuwen vroeger zijn befaamden tocht tot den Oosthoek, thans bepaalde de groote postweg de reisroute. De beteekenis van Daendels' grootsche schepping komt hier treffend uit. Overigens verschilde de sfeer van het land dat men doortrok minder van vijf eeuwen her dan van een eeuw later. Het wild gedierte was nog niet tot verre schuilhoeken teruggedrongen, de mensch deelde de heerschappij over Java nog met de dieren des wouds. De dienstreis van den Gouverneur-Generaal was als een tournée van een Groot-Resident, met inspectie van pakhuizen en 
koffietuinen incluis; de burgerlijkheid was in de plaats getreden van de pracht en praal waarmee een koning van Java door zijn landen trok. De vorst bezocht de bouwwerken langs zijn weg om er zijn devotie's te verrichten, de nieuwe bezoeker stond voor de bouwvallen als een vreemdeling en een vreemde. En zijn kroniekschrijver was geen dichter.

Van Buitenzorg ging men over den Poentjak naar Tjiandjoer. Als iets nieuws wordt ons verteld dat de Regent hier begonnen was koffietuinen in het gebergte aan te leggen, tot dusverre waren blijkbaar de aanplantingen tot de vlakte beperkt geweest.

$\mathrm{Er}$ is wel eens beweerd dat het Nederlandsch bewind aan de Inlandsche bevolking schoolonderwijs zou hebben opgedrongen. Maar in Tjiandjoer was een schooltje waarvoor de patih - de Schr. noemt hem de toemĕnggoeng of tweede hoofd - zich in het bizonder moeite gaf en waar een twintigtal knapen van adellijken huize, waaronder drie zonen van den Regent, onderwijs ontvingen; het zoontje van den Patih las zelfs vrij vlot Nederlandsch. Dit was in 1822, lang vóór de Indische Regeering het Inlandsche Onderwijs ter hand nam. De schrijver noemt hier en verder de Soendaneezen hardnekkig „Javanais”, maar als hij de Pamali-rivier bij de grens van Brĕbĕs en Tĕgal passeert, herinnert hij zich dat zij de scheiding tusschen Javaansch en Soendaasch taalgebied vormt. Hij ontleent die voorstelling aan het volksverhaal, de werkelijke staat van zaken wijkt daarvan af.

De dienstwerkzaamheden waren vele, de postweg, die de reis zooveel vergemakkelijkte, maakte het ook mogelijk den GouverneurGeneraal telkens nieuwe pakketten dienststukken achterna te zenden, die natuurlijk moesten worden afgedaan. Voeg daarbij de tournée's en men zal begrijpen dat de reis meer was dan een plezierreisje. Dat neemt niet weg dat de autoriteiten in de plaatsen waar men langs trok, hun best deden het hooge gezelschap ook iets te zien te geven. Zoo vormt de beschrijving of bloote vermelding der vertooningen die men te aanschouwen kreeg, meteen een spiegel van eenige aspecten van het cultureele leven dier dagen.

\section{III.}

In de Preanger zag men een angkloeng-vertooning, woonde een hertenjacht bij en aanschouwde een sĕnenan. In Radjamandala was een gezelschap van 20 angkloengspelers tevens dansers opgesteld 


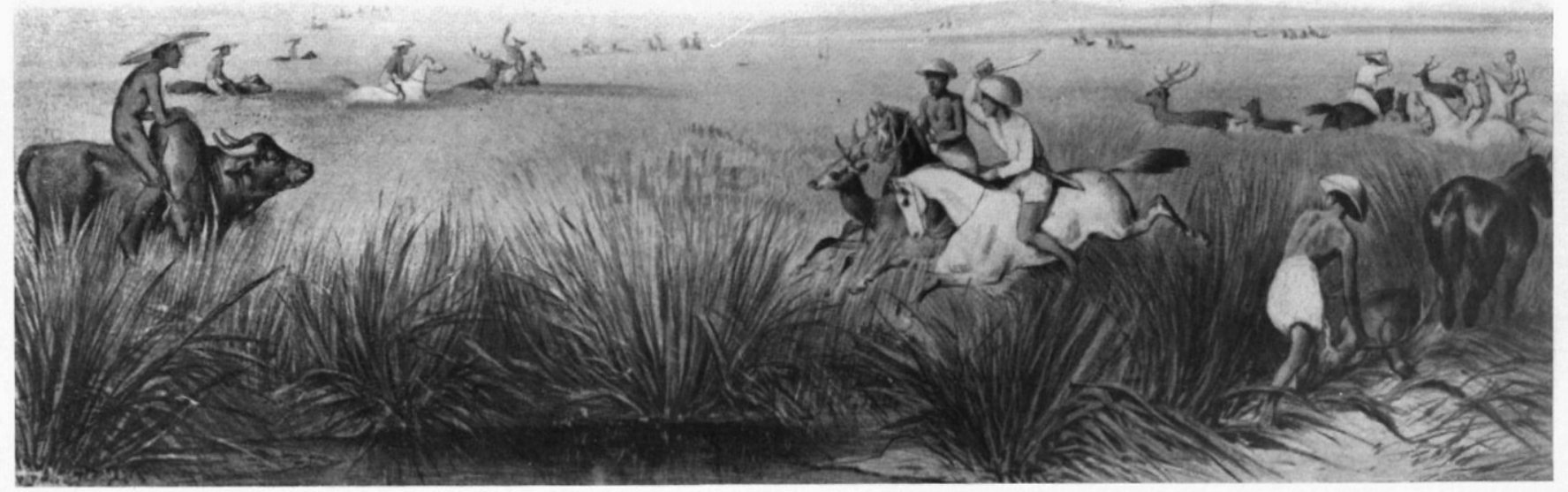

Een hertenjacht op de Bandoengvlakte. 


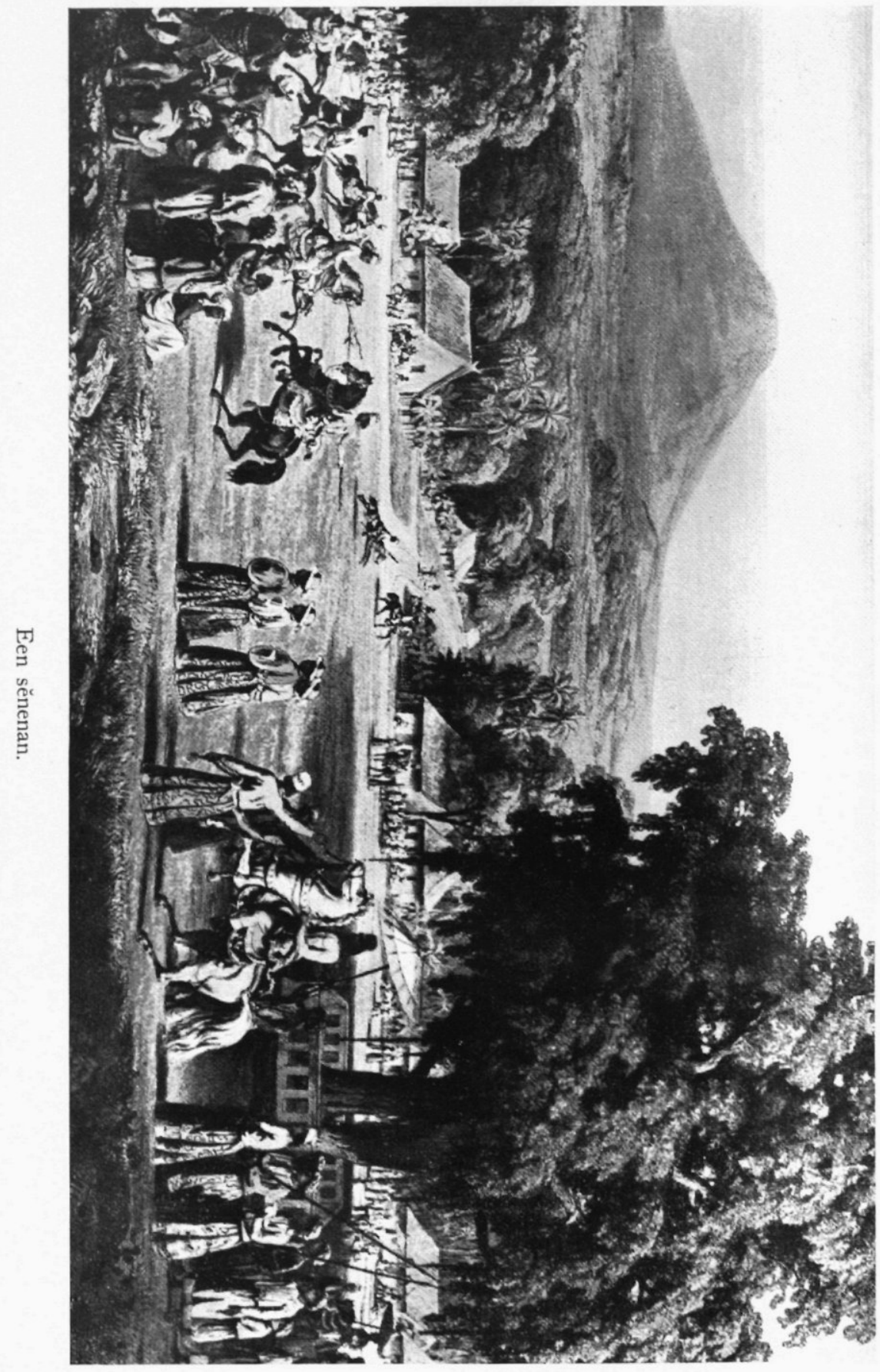


waarvan een belangrijke bizonderheid wordt medegedeeld. $\mathrm{Z}_{\mathrm{ij}}$ hadden een wit koord om het hoofd gewonden dat achterwaarts op den rug afhing, het linkerbeen was wit geverfd, hun eenige kleeding bestond uit ceinturen. Dat zullen wel schaamgordels geweest zijn. Dit costuum of liever ontstentenis van costuum, dat witte koord, die wit gemaakte beenen, versterken het vermoeden dat deze angkloeng groepdans een diepere beteekenis heeft gehad dan een volksvermaak te zijn.

De Regent van Bandoeng had een hertenjacht gearrangeerd. Dit geschiedde aldus dat de herten door ruigte en alang-alang te paard werden nagezet; wanneer de ruiter het hert op zij was gekomen, gaf hij het een doodelijken slag met zijn kapmes. De Bandoengvlakte was bij uitstek het terrein dezer drijfjachten. De uitbreiding van den landbouw maakte er ten slotte een eind aan, omstreeks 1870 werd de laatste jacht gehouden. Een afbeeldig is te vinden in het zelfame werk: „Reise des Grafen Emanuel Andrásy in Ost-Indien, Ceylon, „Java und Bengalen. - Pest z.j.”. De groote, gekleurde plaat, naar een eigen teekening, dateert van 1849. Later heeft de Bie, in een tijd toen de herinnering aan deze jachten nog levendig was, een beschrijving gegeven in het Tijdschrift voor het Binnenlandsch Bestuur I (1887).

De Regent onthaalde verder het gezelschap op een rijsttafel, waar de Schr. naast één der dochters van den Regent gezeten was. Ook verder vernemen wij telkens dat de vorstinnen en de vrouwen der Inlandsche aristocratie met waardigheid haar plaats in het openbare leven innamen.

Soemědang zorgde voor een sěnenan. Zulke tournooien waren toentertijd bij de Inlandsche hoofden nog zeer in eere, vernemen wij. Gewoonlijk hadden zij op den klassieken dag, des Maandags, op de aloen-aloen vóór de kaboepaten plaats. In Soemědang vormde een potsenmaker deel van het tournooi, 't was een dwerg wiens lichaam met veeren was beplakt, hij was gezeten op een klein paardje.

De Noordkust van Midden-Java vertoonde weinig leven. Cheribon was in verval, in Tĕgal had de Resident zijn woning wegens ongezondheid moeten verlaten en woonde nu te Bandjaran, een plaatsje zes paal ten Zuiden van de stad. Toch was de plaats door demping van moerassen minder ongezond dan zij geweest was. Maar daarmee was het laatste woord nog niet gesproken. Niet lang geleden, en misschien nog wel, vormden de zg. Tĕgalsche koortsen nog altijd een schrikbeeld.

In Pamalang keerde men even bij den Regent aan, zijn dochters namen „d'un air modeste" de honneurs waar. Het staatsiepaard van

D1. 100 . 
den Regent dat men even te zien kreeg, was een schimmel met rose geverfde manen en staart. Was dit een gril van den eigenaar of was zoo iets meer gebruikelijk in die dagen?

In Pakalongan was het de Resident die voor allerlei vertooningen zorgde : kunstenmakers, tandakpartij en wajangspel. De schrijver doet nu en dan opgaven van het zielental der gewesten. Zoo ook hier. Het kleine Pakalongan (Pakalongan + Batang, toenmaals nog kleiner dan nu) had een bevolking gelijk aan die der Preanger Regentschappen, het al even kleine Kĕdoe had ruim anderhalf maal zooveel inwoners, het was dus ook onder Javaansch bestuur reeds dicht bevolkt, want het was in 1812 door Jogjakarta afgestaan.

De postweg van Batang naar Wěleri, het eerste station op Samarangschen bodem, liep veel zuidelijker dan tegenwoordig, hij ging voor een groot deel door toen nog Vorstenlandsch gebied („Delimas” Sala'sch, Limpoeng Boeloe en Tĕrsana Jogjaasch). Het blijkt telkens dat de weg van Daendels haastig was aangelegd en in de berggedeelten omleggingen noodig waren. In Tjiandjoer had de Regent juist een omlegging bij de Tjisokan tot stand gebracht, de befaamde Tjadas Pangeran bij Soemědang was juist gereed gekomen, de thans gevolgde weg van Batang naar Wĕleri zou ook later door een anderen vervangen worden.

Door het district Kĕndal dat nog één uitgestrekt woud was, kwam men in Samarang. De Regent zorgde voor verschillende feestelijkheden. Er was een sĕnenan, een gevecht van een tijger met een buffel, dat mislukte omdat beide dieren pacifistisch waren en een schouwspel dat in het bizonder bestemd was de vroolijkheid der menigte te wekken: in een afgesloten ruimte waren wilde zwijnen, honden, bokken en een aap tesamen gebracht, die achter elkaar aan. draafden als in een film.

Men was nu in Midden-Java, de steenen beginnen te spreken. Telkens hoort men nu van bezoeken aan oudheden. Eenig besef van de merkwaardigheid daarvan was er dus wel, maar toch zeiden we te veel toen we de steenen lieten spreken. Dat deden zij niet. De Hindoe-Javaansche oudheden stonden daar veeleer als stomme getuigen van een grootsch verleden, maar de bezoekers waren daar nog te onkundig van dan dat de steenen hun iets te zeggen hadden.

IV.

In Samarang werd de groote postweg verlaten om een bezoek aan Soerakarta en aan Jogjakarta te brengen. Op weg daarheen, in Sala- 


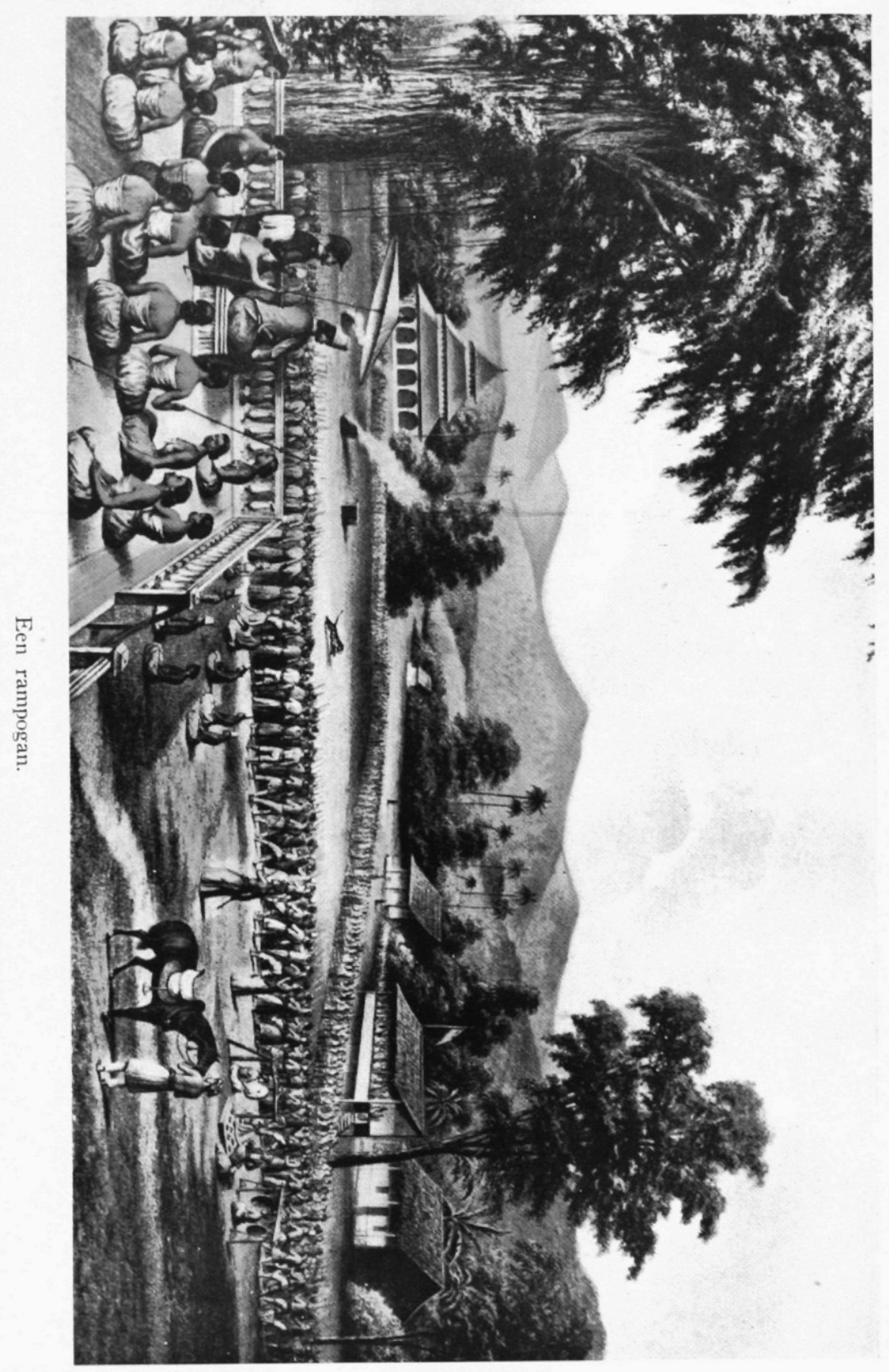


tiga, vermeldt de schrijver in de nabijheid van het dorp een bron en badplaats, waarmee hij waarschijnlijk Kalitaman bedoelt. Hij doet ook het verhaal dat zich daar vroeger drie tempels verhieven, waar hooge vrouwen het uitsluitend recht hadden te baden. Dit gelijkt meer op badplaatsen. Ook het vervolg, dat de steenen gediend hebben om het fort ter plaatse te bouwen, deelt hij mede, maar dit zegt hij onder voorbehoud (Krom, Inleiding Hindoe-Javaansche kunst I 316). 't Is moeilijk te zeggen of deze bouwwerken iets te maken hebben met het kapelletje dat de onderkoopman Lons in 1733 te Salatiga vermeldt. Inlandsch hoofd van Salatiga - de Schr. noemt hem Dĕmang, misschien zelfstandig patih - was Raden Rana di Poera, dezelfde wiens geteekend portret tegenover het titelblad der History of Java staat. Hij was door Raffles naar Engeland meegenomen, maar zijn Engelsch was hij vergeten, als hij het gekend heeft, voegt de Schr. erbij. Hij geleek niet op het portret.

Men naderde de Vorstenlanden. In Bajalali wachtte Mangkoenagara, in Kartasoera de Soesoehoenan in eigen persoon den Gouverneur-Generaal op. In een statigen optocht, die met de nauwkeurigheid van een protocol bescheven wordt en omstuwd door de menigte ging het toen naar de hoofdplaats. De vertooningen welke de Soesoehoenan zijnen gasten liet zien, waren vele. Op een avondpartij ten Residentiehuize gaven twee maal vier sarimpi's, in draagstoelen van de Kraton daarheen gebracht, een voorstelling. In de Kraton was een strijd van buffel en tijger te aanschouwen. 't Schijnt wel dat dit een traditioneel schouwspel voor hooge bezoekers was. De Sultan van Jogjakarta deed desgelijks. Beide vorsten zorgden ook voor een rampogan, in Sala lieten daarbij vier, in Jogja drie tijgers het leven. Het gevecht tusschen den tijger en den buffel ging in Sala ook op wat grooter schaal, twee tijgers werden door den buffel geveld, in Jagja bleef het bij één slachtoffer.

De Soesoehoenan bracht de bezoekers bij een bassin waarin hij een krokodil hield, later in Jogja zag men, vermoedelijk op de zuidelijke aloen-aloen, twee met roode doeken bekleede olifanten. De Schrijver bezocht van Karangpandan uit de oudheden van Soekoeh, de terrassen waren met gebeeldhouwde steenen waaronder hem in het bizonder garoeda's opvielen, als bezaaid. Hij vertelt van het beeld van het everzwijn met horens waaraan de Javanen het vermogen toeschreven wilde varkens - om in Indischen stijl te blijven - te verjagen naar de richting waarheen de kop gewend was. Met dit beeld moet het relief bedoeld zijn dat nu nog aanwezig is. 
Het waterkasteel in Jogja verkeerde toen reeds in staat van verval.

Bekend is de steen van Pasargĕde waarvan Buddingh in 1839 in het Tijdschrift van Nederlandsch-Indië II Jaargang dl. 1 blz. 45 v.v. het inschrift bekend heeft gemaakt, met facsimile, hetwelk door Brandes in de Notulen van het Bataviaasch Genootschap XXXVIII (1900) blz. 109 v.v. opnieuw aan een bespreking is onderworpen. Sedert heeft Lekkerkerker alles wat hem over dezen steen bekend was, in een artikel in Tijdschrift Batav. Gen. LXXVIII 167 v.v. bijeengebracht. Doch nu blijkt dat Buddingh een voorganger heeft gehad: de onbekende schrijver der „Lettres de Java” heeft in 1822 het inschrift reeds gelezen. Buddingh zegt dat deze groote, gladde, blauwe steen op een kleine verhevenheid onder twee oude en hooge waringinboomen geplaatst was, onze Schr. spreekt van een omheining waarbinnen onder de schaduw van een waringin de steen lag. Hij was verbaasd er een inschrift op te vinden dat hij letterlijk aldus weergeeft :

In het midden, met de bovenzijde te beginnen, zie pijl op de afbeelding:

Ad aeternam memoriam sortis infelicis $\mathrm{I}$. G. M.

Om deze woorden in een kring, rechtsom:

Ainsi va le monde.

Zoo gaat de waereld.

Cosi va il mondo.

Ita movetur mund s.

Om den kring een vierkant, door de volgende zinnen gevormd:

Infortuna consortes digni valete

Quid stupearis insani

Videte ignari et ridete

Contemnite vos contemtu vere digni

Verder, hier en daar, de volgende voorden:

Amelan LII

Jovi

CID inv. D cur. LX vid. IX leg.

Son gout $P$

Het merkwaardigste is wel dat de Schr. hier, als het ware langs zijn neus weg, het jaartal 1569 gelezen heeft. De Letters I G M bij Buddingh en Brandes, schrijft hij I. G. M. met punten. Vrage: is van 
SONG OUT P

CONTEMNITE VOS CONTEMTI VERE DIGNI

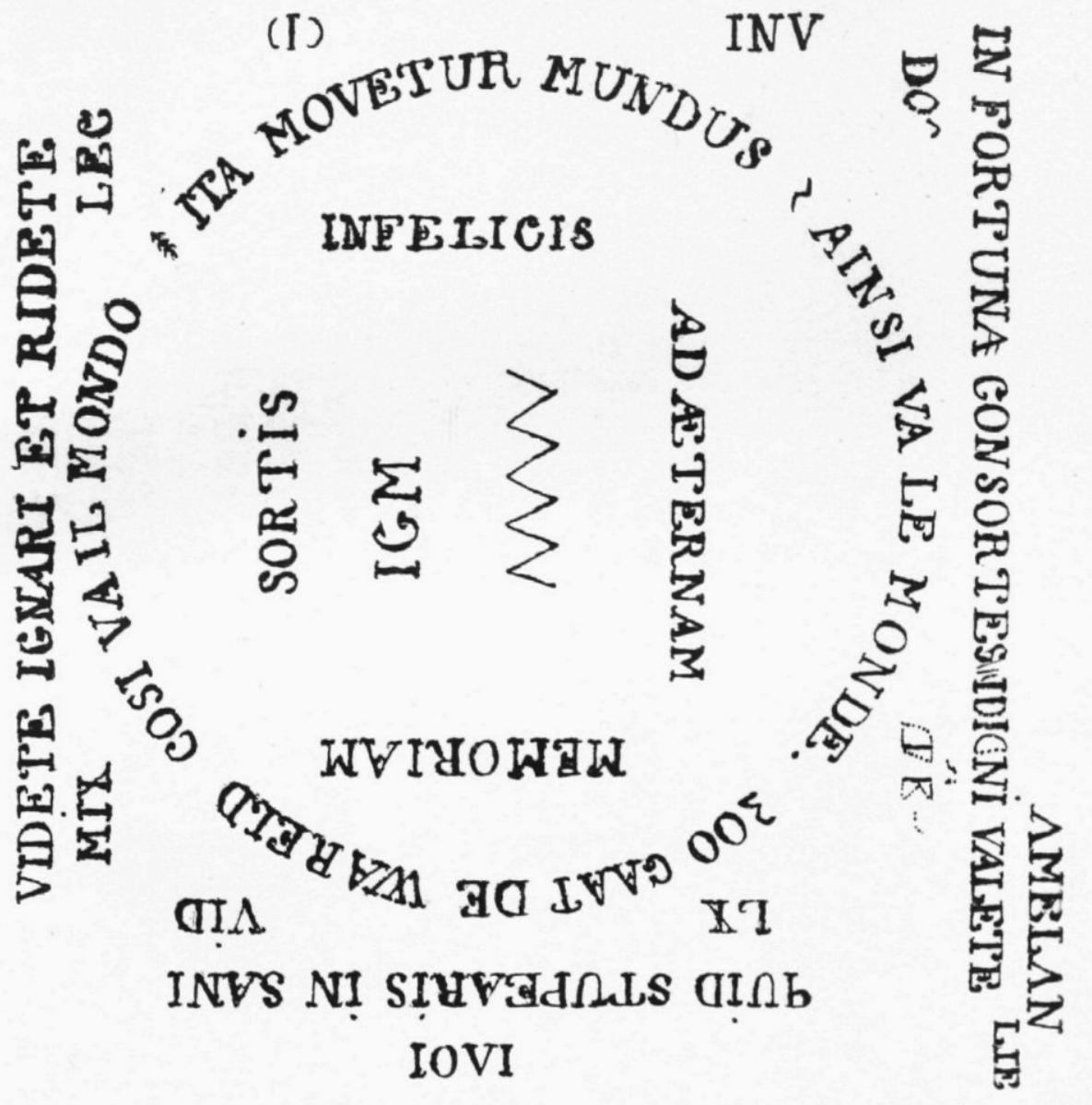

De beschreven steen van Pasar gĕḍe. (Naar Buddingh.) 
die punten nog iets te vinden? Het is waar dat hij achter andere afkortingen ook punten schrijft, waar zij bij Buddingh en Brandes ontbreken. Blijkbaar heeft hij de drie letters als initialen beschouwd van een eigennaam. De transcriptie ,waereld" is waarschijnlijk incorrect daar èn Buddingh èn Brandes ,wareld” lezen. Zoo ook ,mundes" voor ,mundus", of mogelijk een drukfout. Achter Amelan leest hij LII, Buddingh L I E, Brandes idem, met een vraagteeken. Het cijfer der honderdtallen van het jaartal is bij hem D, Budding D On, de $\mathrm{O}$ onduidelijk, Brandes meent ID (?) onduidelijk, thans blijkt wel dat 5 , hetzij $D$ hetzij $I D$, juist is. Boven rechts, onder ,digni” staat iets wat Buddingh niet heeft kunnen lezen, Brandes las CUR, onze Schr. geeft hetzelfde, getranscribeerd cur. Ten slotte leest hij links onder: Son gout p, Budding SONG OUTP, Brandes: SONG UTP. Ik ben geneigd aan te nemen dat de $\mathrm{O}$ die de beide andere waarnemers lazen er werkelijk gestaan heeft.

De vragen die de steen stelt, zijn hiermee niet opgelost, maar 't leek me van voldoende belang Schr.'s lezing mede te deelen, juist omdat zij de oudste is en hem in allen gevalle, evenzeer als Brandes, de eer toekomt, het jaartal uitgevonden te hebben.

Op den terugweg van Jogjakarta naar Samarang werd een bezoek gebracht aan de Baraboedoer. De hoofdstoepa (,une petite coupole”, ..., ,au centre") was ledig, zegt de Schr.: Dit kan echter niet juist geweest zijn, want twintig jaar later werd bij de opruimingswerkzaamheden die resident Hartmann liet instellen, een onafgewerkt Boeddhabeeld gevonden (Krom, Handleiding tot de Hindoe-Javaansche kunst I 259). Als souvenir nam hij een kleinen Boeddha-kop mede! ,que je compte conserver soigneusement pour vous [d.i. de „,vriend in patria] la montrer".

V.

In vroeger tijd was het mogelijk, althans in den regentijd, van Djoewana de Djoewana-rivier op te varen tot de Rawa běsar en vandaar langs verschillende waterwegen Samarang te bereiken. Zoo was het nog in de dagen van Stavorinus (1774); prauw majang's volgden, vooral in den kwaden moesson, deze route ten einde het gevaarlijke vaarwater benoorden Djapara om te ontgaan (Stavorinus, Reize ... naar Samarang enz. I 122. - Leiden 1797). Daendels heeft door het graven van een kanaal in het Dĕmaksche den weg trachten 
te verbeteren. Het was er nog in 1822, maar het was ook de bedoeling geweest dat de uitgestrekte moerassen die zich hier bevonden, zouden droog komen te liggen, dat doel was, naar Schr. constateert, niet bereikt.

In Koedoes of Pati, de plaats wordt niet precies genoemd, nabij de Rawa běsar, was een vijver die door oude schildpadden bevolkt werd, zoo oud dat haar schilden met witte vlekken van ouderdom bedekt waren. $\mathrm{Zij}$ waren zoo aan de menschen gewend dat zij, als honden, tegen hen op gingen staan als haar voer voor gehouden werd. Volgens het verhaal vormde de vijver deel van een oud buitenverblijf van den Sultan van Děmak. De bevolking bracht aan deze schildpadden des Vrijdags gekookte rijst. Schippers en handelaren die van Djoewana in zee staken, brachten hun offers naar een plaats van vereering nabij een boom, waar de apen uit den omtrek hun vergaderingen hielden. Dezelfde apen plachten de pasar te Trangkil (ten Noorden van Djoewana, aan den weg naar Tajoe) te bezoeken terwijl die in vollen gang was en wachtten dan rustig den afloop af om zich aan het afval te goed te doen. De Schr. staat voor de waarheid in. Men wordt hier herinnerd aan de welbekende apen van Blauwwater bij Pasoeroehan.

Ook op den verderen tocht had de Schr. gelegenheid plaatsen te bezoeken waar de dieren zich in het leven der menschen mengden. Ziehier een levende inleiding tot den ouden tijd en de oude litteratuur toen de levens van mensch en dier zich nog veel vaker kruisten of in elkaar opgingen. Zoo werd de grot van Rengĕl in het Toebansche door drie slangen bewaakt, waarvan de bezoekers er één zagen, et waren ook schildpadden en apen, ,des prêtres sont chargés de là „protection”, d.w.z. er waren kijai's die als tusschenpersoon tusschen menschen en dieren fungeerden. Het hoofd der apen had een eigen naam, Mas Nala.

Men krijgt eenig denkbeeld der beteekenis van den scheepsbouw aan Rĕmbang's kuste als men hoort dat er een oorlogsfregat gebouwd werd en twee schoeners voor de Gouvernementsmarine, de Circe en de Nautilus, nagenoeg voltooid waren.

Zoo kwam men dan, twee maanden na Batavia verlaten te hebben, in Soerabaja aan. Ook hier was een centrum van scheepsbouw. Te Boenga aan de Sala-rivier was een Gouvernementsscheepstimmerwerf, waar sedert 1818, dus in vier jaren, gebouwd waren: een brik, de Orestes, 4 schoeners, 2 aken, 2 kiellichters en 16 kanonneerbooten. Dat is heel wat maar het waren allen kleine vaartuigen. Het grootste 
op Java gebouwde schip, dat in Grěsik thuis behoorde, mat niet meer dan 700 ton.

VI.

Thans ving de reis door den Oosthoek aan. De Schr. prijst de schoonheid van den Tĕnggĕr welke deels van uit Pasoeroehan, deels op den terugweg, met Prabalingga als uitgangspunt, werd bezocht, doch overigens bepaalt hij zich ertoe aan te halen en te beamen wat een Fransch natuuronderzoeker, Leschenault de la Tour daarover, naar hij meent in 1805 , op schrift had gesteld. De aanhalingen zijn lang maar leveren niets opmerkelijks. Over dezen man die in dienst van Nicolaus Engelhard een botanische reis door Oost-Java maakte, is een en ander te vinden in: de Haan, Priangan I 85.

Een ander bezoek gold het meer Klinḍoengan bij Grati en $\mathrm{Ba}-$ njoebiroe of Blauwwater, beiden bij toeristen nog steeds welbekend. Het meer was een plaats van vereering waar de bevolking aan de daar huizende krokodillen en lele-visch offeranden bracht, hetzelfde viel den tambra's (soort karpers) bij Banjoebiroe ten deel.

Het laatste gedeelte der reis was tevens het somberste. Van $\mathrm{Pa}$ naroekan tot Banjoewangi was het land woest en ledig, althans van menschen, niet van dieren. Het wemelde er van tijgers. Het Gouvernement had jagers in dienst wier eenige taak bestond in het jacht maken op deze dieren. In deze woesternij, bosch en wildernis vormde Banjoewangi een oase. Hier speelde, werd den Schrijver verteld, zich eenmaal de geschiedenis van Sri Tandjoeng af. Dr. Prijono die dit oude, Javaansche verhaal heeft uitgegeven (Leiden 1938) zegt in de Inleiding dat het, zooals het in den volksmond in Banjoewangi voortleefde, het eerst door F. Epp in 1849 werd opgeteekend. Onze Schr. blijkt het in 1822 ongeveer juist zoo gehoord te hebben. Het geurende water, Banjoewangi, waarnaar het oord heet, was echter volgens zijn zegslieden geen beek maar de bron die tegenover de Regentswoning, overigens een onaanzienlijke huizinge, ontsprong.

Op den terugweg werd halt gehouden te Basoeki. Hier ontpopte de Schr. zich als een staatsgevaarlijke revolutionnair. De Regent sprak vrij goed Nederlandsch. Het wordt ons zonder ontsteltenis, zonder verontwaardiging meegedeeld. Honderd jaar later was het ras der Nederlanders die het beneden hun nationale waardigheid achtten met een Javaan Nederlandsch te spreken, laat staan zich door hem in het Nederlandsch te laten toespreken, nog niet uitgestorven. Dan liever brabbel-Maleisch! 
Behalve deze onbeschaamdheid had de Regent nog iets anders voor zijn gasten in petto, de strijd tusschen twee stieren. Het is niet duidelijk maar wel waarschijnlijk dat hiermee twee bantengs bedoeld zijn. De kamp leverde niet op wat ervan verwacht was, want aan beide zijden ontbrak alle vechtlust.

Van uit Pasoeroehan werden eenige oudheden bezocht. Eerst Indrakila. Wat de Schrijver hiervan zegt, wijkt van Domis die er in 1830 heentrok, af. Hij zag vier reusachtige beelden van gezeten figuren van ongeveer 12 voet hoogte, tempelwachters (rākshasa's). Zij hadden met drie doodshoofden versierde banden om het hoofd, slangen als arm- en beenbanden en een groote slang als sjerp. Hij zag er voorts 2 olifanten, 2 tijgers, 2 honden, 2 pauwen, 2 eenden en 2 tortelduiven. De olifanten waren vermoedelijk Ganeça's, wat de andere voorstellingen waren, blijve in het midden.

$\mathrm{Na}$ Indrakila volgde Singasari: vijf blootgelegde, kleine tempels, muurresten en gemetselde vijvers. In de omgeving der dorpjes Mandaraka, Karanglo en Dinaja waren verschillende gemetselde kelders, 12 à 14 voet hoog met puntdaken en 8 à 10 voet diep in de aarde gaande. Dit doet aan tempelkamers denken. Van Djadjawi, aldus genoemd ,Jejawi”, wordt alleen een oude put vermeld met de daaraan verbonden legende. Als naam wordt "Souwajouwo" opgegeven. Op het erf der assistentresidentswoning te Malang waren o.a. beschreven steenen opgesteld.

Madoera kreeg een beurt toen het gezelschap in Soerabaja terug was. Het bezoek duurde slechts kort en beperkte zich tot den dalěm van den Sultan van Madoera te Bangkalan. Veel was hier niet te zien maar de reizigers troffen nog de overblijfselen aan van een optocht die ter gelegenheid van het huwelijk van een dochter van den Sultan gehouden was, de garoeda-wagen met bewegelijke vleugels waarin het bruidspaar had plaats genomen en monsterpoppen (barongan's).

De terugreis van Soerabaja naar Batavia geschiedde over zee en leverde niet bizonders op, 5 November zette men te Batavia weder voet aan wal na ruim drie maanden weg te zijn geweest.

Leiden, 26 April 1940. 


\section{BESCHRIJVING DER PLATEN.}

Reis per postwagen. In de 19e eeuw werd langs de heirwegen van Java per postwagen gereisd. G. G. van der Capellen volbracht aldus zijn reis over Java.

Op vaste afstanden waren postloodsen opgericht waarvan men er rechts één ziet afgebeeld. Hier werden de paarden gestald en konden de reizigers zich, beschut tegen regen en zon, tijdens het verspannen ophouden. In het midden, meer op den achtergrond, ziet men een wagen, van drie spannen versche paarden voorzien, door voorrijders voorafgegaan, en talrijke Inlandsche hoofden gevolgd, allen te paard, wegrijden. Zoo ging het in gestrekten draf of in galop tot de volgende post. Op steile gedeelten moesten buffels te hulp komen om den wagen tegen de helling op te trekken. Dan werden vaak twee of drie span buffels vóór de paarden gekoppeld en als de weg zeer steil was, spande men de paarden wel af en werd de wagen alleen door buffels getrokken tot acht toe. Op deze wijze werd tot in het begin der $20 \mathrm{e}$ eeuw gereisd.

De plaat is ontleend aan het plaatwerk: A. SALM; Java. - Amsterdam z.j., zij stelt de groote postweg van Buitenzorg langs het particuliere land Tjisaroewa over den Megamĕndoeng naar de Preanger Regentschappen voor. Een deel van het reisgezelschap van G. G. van der Capellen gaf er de voorkeur aan het steilste gedeelte te voet af te leggen, de G. G. zelf ging te paard. Op het hoogste punt, den Poentjak, gekomen, stapte men weder in de rijtuigen om in ijlende vaart dalwaarts naar Tjiandjoer te snellen.

Een hertenjacht op de Bandoeng-vlakte. Als gast van den Regent van Bandoeng sloeg de G.G. van uit een hoog paviljoen een hertenjacht gade. Zulke jachten werden met goedvinden der Regenten van tijd tot tijd gehouden. In plaats van met kapmessen werd ook wel eens met lasso's gejaagd, steeds op het ongezadelde paard.

Het werk van Andrásy dankt zijn waarde minder aan den tekst dan aan de door hem zelf vervaardigde teekeningen. Ook deze plaat is van zijn eigen hand en geeft de door hem meegemaakte jacht weer.

Het terrein is met alang-alang begroeid. Een groot aantal ongekleed op buffels gezeten ruiters vormden een cordon om het uitgestrekte jachtterrein waar zij de herten binnen hielden. Links ziet men tot aan den gezichtseinder een deel van dit cordon. Deze ruiters 
laadden de gedoode dieren op de schoft van hun rijdier, zooals aan de man op den voorgrond te zien is. Binnen het cordon rennen de jagers achter de herten aan, kris en kras door het terrein. De jacht was niet ongevaarlijk, zij vereischte vasten zit en onverschrokkenheid. Menig ruiter stortte van zijn paard en verongelukte.

Er werden bij zoo'n gelegenheid ware slachtingen aangericht. Op de jacht die graaf Andrásy meemaakte, werden 162 herten neergelegd en 18 jonge dieren levend gevangen.

E e n š̆n en a n. De sĕnenan, aldus genoemd naar den dag waarop zij gehouden placht te worden (Sěnen $=$ Maandag) was een ridderspel van Javaanschen huize. De G.G. woonde het te Soemĕdang bij, dus in Soendaasch gebied. Dit komt hiervandaan dat de Soendasche regenten in kunst en spel de Javanen eenigermate navolgden. In het Javaansche land zag men een sĕnenan in Samarang.

Rijcklof van Goens geeft de volgende, tevens oudste beschrijving van een sĕnenan zooals zij aan het Hof van Mataram in de $17 \mathrm{e}$ eeuw gehouden werd $^{\mathbf{1}}$ ) :

„Den Koningh alleen is rondsom sijn Paert besloten in 2 a 300 „Mannen te Voet / die hem besingelen ende over al versellen / tot ,dat hij een keer met alle d'andere Heeren te Paerde rondsom 't „pleyn [de Noord-aloen-aloen] gedaen heeft. Yder Ruyter heeft een „stompe Lancie (ofte pieck voor met een pop [prop] in de handt. „Soo nu den Koningh selver lust heeft te rennen / eyscht hy yemant ,uyt den hoop ende loopt voor op een volle galop / sijn Voet-volck „hem ter zijden met alle macht na-volgende; den uyt-geeyschten ,volght den Koningh op 't spoor met alle macht / sijn devvoir doende „den Sousouhounan van achteren binnen de langhte van sijn Lancie ,in te rijden / om hem te betoonen dat hy na hem soude konnen „steecken. Den Koningh daer-en-tegen om met sijn Lancie de steecken ,,van achteren te pareren / ende selfs hem te steecken. .... Den Ko,ningh aldus defenderende gekomen zijnde aen 't eynde van 't „Pleyn / went sich om / gelijck ook die hem geoffenceert heeft / die ,dan soodanigh als eerst den Koningh voorloopt ende pareert met een ,gedraeyt lichaem de steecken die hem de Koningh (nu offencerende) „,soeckt te brengen soo lange / datse beyde op de plaetse van waerse ,begonnen / gekomen zijn: ofte anders hervatten sy dit Tournoy-

1) Javaense Reyse / Gedaen van / Batavia / over / Samarangh / Na de Konincklijke Hoofd-plaets / Mataram / Door de Heere N.N. in den Jare 1656, p. 13 v.v. - Dordrecht 1666 . 
„spel / soo lange tot dat een van beyde voordeel op sijn party schijnt „gehadt te hebben: tot dien eynde veranderense elcke reys van Paer,den / die yder Heer tot 4 a 5 by sijn Huysken staen heeft".

Onze afbeelding, ontleend aan: De Indische Archipel. - 's-Gravenhage 1876 , wellicht in de jaren tusschen 1860 en 1870 vervaardigd, stelt en aloen-aloen voor waarvan men zich moet voorstellen dat de ommuurde waringin's aan de rechterzijde het middelpunt vormen. Een Javaansche groote in hof-kostuum komt hier in staatsie het terrein oprijden. Links hebben tournooien plaats waarbij het opvalt dat de ruiters niet achter elkaar aanrijden zooals van Goens ons beschrijft maar op elkaar in rennen als in de Middeleeuwsche riddersteekspelen. In het midden op den achtergrond rijden een paar ruiters die hun beurt gehad hebben, weg, een ander staat, een weinig rechts, gereed aan het tournooi deel te nemen.

In de tweede helft der 19e eeuw is dit ridderlijk spel in onbruik geraakt.

Een rampogan. De plaat is uit hetzelfde werk als die van de sěnenan genomen en dateert uit denzelfden tijd.

Rampogan's zooals het reisgezelschap van den G.G. in Soerakarta en in Jogjakarta te aanschouwen kreeg, bestonden hierin dat gevangen koningstijgers in kooien op de aloen-aloen werden gebracht. Een groot aantal, met lansen gewapende Javanen stelden zich in meerdere rijen rondom de aloen-aloen en carré op. De hoop, die niet altijd in vervulling ging, was dat de tijger, geen uitweg ziende, zou trachten ergens over de haag van lansen heen te springen en de kunst was nu hem op die lansen op te vangen. 't Kon zijn dat de tijger zijn sprong zoo hoog nam dat hij over de lansen heen sprong en ontsnapte, maar ook dat het dier geen lust toonde den sprong te wagen.

Als de kooi werd opengezet, werd ze meteen aan de achterzijde in brand gestoken om den tijger te dwingen naar buiten te komen. Op de plaat ziet men twee zulke rookende kooien, de derde herbergt haar inhoud nog. Het gebouw op den achtergrond is de moskee; op den voorgrond slaan links een Javaansch vorst met den Resident, beiden in groot-costuum, van een verhevenheid het schouwspel gade. 